Article

\title{
Pan-Drug Resistant Acinetobacter baumannii, but Not Other Strains, Are Resistant to the Bee Venom Peptide Melittin
}

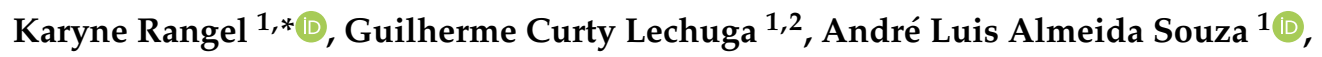 \\ João Pedro Rangel da Silva Carvalho ${ }^{1}$, Maria Helena Simões Villas Bôas ${ }^{3}$ and \\ Salvatore Giovanni De Simone ${ }^{1,4, * \text { (D) }}$ \\ 1 FIOCRUZ, Center for Technological, Development in Health (CDTS)/National, Institute of Science and \\ Technology for Innovation in Neglected Population Diseases (INCT-IDPN), Rio de Janeiro 21040-900, Brazil; \\ guilherme.lechuga@yahoo.com.br (G.C.L.); alsouza@ioc.fiocruz.br (A.L.A.S.); \\ joaopedrorsc@gmail.com (J.P.R.d.S.C.) \\ 2 FIOCRUZ, Oswaldo Cruz Institute, Laboratory of Cellular Ultrastructure, Rio de Janeiro 21040-900, Brazil \\ 3 FIOCRUZ, Microbiology Department, National Institute for Quality Control in Health (INCQS), \\ Rio de Janeiro 21040-900, Brazil; maria.villas@incqs.fiocruz.br \\ 4 FIOCRUZ, Federal Fluminense University, Biology Institute, Department of Molecular and Cellular Biology, \\ Rio de Janeiro, Niterói 24020-140, Brazil \\ * Correspondence: karynercarvalho@gmail.com (K.R.); dsimone@cdts.fiocruz.br (S.G.D.S.)
}

Received: 6 November 2019; Accepted: 14 December 2019; Published: 14 April 2020

\begin{abstract}
Acinetobacter baumannii is a prevalent pathogen in hospital settings with increasing importance in infections associated with biofilm production. Due to a rapid increase in its drug resistance and the failure of commonly available antibiotics to treat $A$. baumannii infections, this bacterium has become a critical public health issue. For these multi-drug resistant $A$. baumannii, polymyxin antibiotics are considered the only option for the treatment of severe infections. Concerning, several polymyxin-resistant $A$. baumannii strains have been isolated over the last few years. This study utilized pan drug-resistant (PDR) strains of A. baumannii isolated in Brazil, along with susceptible (S) and extreme drug-resistant (XDR) strains in order to evaluate the in vitro activity of melittin, an antimicrobial peptide, in comparison to polymyxin and another antibiotic, imipenem. From a broth microdilution method, the determined minimum inhibitory concentration showed that $S$ and XDR strains were susceptible to melittin. In contrast, PDR A. baumannii was resistant to all treatments. Treatment with the peptide was also observed to inhibit biofilm formation of a susceptible strain and appeared to cause permanent membrane damage. A subpopulation of PDR showed membrane damage, however, it was not sufficient to stop bacterial growth, suggesting that alterations involved with antibiotic resistance could also influence melittin resistance. Presumably, mutations in the PDR that have arisen to confer resistance to widely used therapeutics also confer resistance to melittin. Our results demonstrate the potential of melittin to be used in the control of bacterial infections and suggest that antimicrobial peptides can serve as the basis for the development of new treatments.
\end{abstract}

Keywords: Acinetobacter baumannii; multidrug resistance; pan drug resistance; melittin; biofilm; antimicrobial peptide

\section{Introduction}

The emergence of drug-resistant strains of major pathogenic bacteria is an increasingly critical public health issue [1,2]. One such pathogen is the Gram-negative bacterium Acinetobacter baumannii, which possesses both multidrug resistance (MDR) genes and an intrinsic natural resistance toward 
many currently available antibiotics that can lead to untreatable infections [3,4]. The Centers for Disease Control and Prevention (CDC) categorized MDR Acinetobacter as a serious threat requiring continuous public health monitoring and prevention activities [5]. To date, A. baumannii has shown resistance to a large spectrum of cephalosporins, aminoglycosides, fluoroquinolones and carbapenems as well as polymyxins, a last-resort class of antibiotics [6-8]. In 2017, the World Health Organization (WHO) released a priority list of pathogens threatening human health and classified $A$. baumannii as the top critical pathogen for research and development of new antimicrobials [9].

Another critical issue for treatment of $A$. baumannii is its ability to form biofilms, the structured surface-associated multicellular communities of microbes that are encased in an extracellular matrix consisting of proteins, lipids, nucleic acids and polysaccharides [4]. The formation of a biofilm can be a major contributor to treatment failures as its structure can create a physical barrier that prevents antibiotic delivery [10-13]. In addition to providing greater protection against antibiotics, biofilms can also interfere with host immune defenses and isolate bacteria from adverse environmental conditions [14]. It is estimated that $65-80 \%$ of human infections are caused by biofilm-forming bacteria [15], which is responsible for considerable morbidity and contribute significantly to healthcare costs [16-18]. Regarding A. baumannii, it can form biofilm communities on most abiotic surfaces in hospitals, such as stainless steel and polycarbonate, that can lead to the contamination of equipment, prosthetics, endotracheal tubes, and catheters, as well as biotic surfaces of patients including skin, lung, heart, bladder and other organs [19].

Therapeutic options for multidrug-resistant (MDR) strains of A. baumannii infections are limited. One promising source of novel treatments is antimicrobial peptides (AMPs), which have gained increased attention as one of the main options to overcome antibiotic resistance [20,21]. AMPs are typically short peptides (i.e., 2-100 amino acids) that incorporate mostly cationic, hydrophobic and amphipathic properties [22-24]. In nature, they are a component of the first line of defense against invading microbes in the host immune defense system of all classes of organisms including microorganisms, plants, insects, fish, reptiles, and mammals [22,23]. The interest in applying AMPs as a therapeutic alternative against pathogenic microorganisms is related to their potency, rapid action and display of a broad spectrum of activities against both gram-negative and gram-positive bacteria as well as viruses, fungi and parasites $[21,25,26]$. The main mechanism of action attributed to AMPs against pathogens is to target microbial membranes for disruption, destabilization or permeabilization via their formation of pores [23]. Additional mechanisms have been described related to the intracellular translocation of the peptide that can inhibit macromolecular synthesis including DNA, RNA and proteins [27].

One of the most extensively studied AMPs is a major component in the venom of European honeybee Apis mellifera, melittin [28]. Melittin has demonstrated a wide range of bactericidal activity against both reference and clinical strains [28-30], which includes antibiotic-resistant bacteria, such as A. baumannii and Pseudomonas aeruginosa [31-33]. It is a small cationic linear peptide composed of 26 amino acid residues (GIGAVLKVLTTGLPALISWIKRKRQQ-CONH${ }_{2}$ ) with a net charge at physiological $\mathrm{pH}$ of +6 due to the presence of arginine and lysine residues [22,34]. The N- and C-terminal amino acids of melittin are mostly hydrophobic and hydrophilic, respectively [28,35]. Polar and nonpolar amino acid residues are distributed asymmetrically in melittin, suggesting an amphipathic nature when it adopts in an $\alpha$-helical conformation [36]. This cationic and amphipathic structure is regarded as the most characteristic configuration of AMPs, which makes melittin a representative model peptide for understanding the mechanisms of membrane permeabilization by AMPs [28,37,38].

Melittin has also been shown to exert a problematic allergy-based activity by increasing serum immunoglobulin E (IgE) in nearly one-third of honeybee venom-sensitive individuals [39]. Besides, melittin can be incorporated into the phospholipid bilayers of cell membranes that induce dose and time-dependent morphological changes leading to cell lysis. Thus, possible adverse effects of melittin should be considered before evaluating their possible therapeutic applications. Recently, a study 
demonstrated that topical administration of melittin at concentrations of 16 and $32 \mu \mathrm{g} / \mathrm{mL}$ in mice killed $93.3 \%$ and $100 \%$ of an XDR A. baumannii on a third-degree burned area, respectively [32]. No toxicity was observed on injured or healthy derma, as well as circulating red blood cells in the examined mice. This finding has encouraged further investigations to re-examine the application of naturally occurring AMPs for at least topical treatments, which have been understudied due to the potential toxicity against mammalian cells.

Here, we report on an evaluation of the in vitro activity of melittin against multiple strains collected in Brazilian hospitals that could be described as susceptible (S), extreme drug-resistant (XDR), and pan drug-resistant (PDR). The peptide was also tested for effectiveness against biofilms and its membrane lysing properties by fluorescence microscopy.

\section{Materials and Methods}

\subsection{Bacterial Strains}

Four A. baumannii strains were collected from two public hospitals in Rio de Janeiro: one (31852) that was susceptible to eleven antimicrobials tested of six groups, two (33677 and 96734) that harbor bla $a_{\mathrm{OXA}-23}$ genes representing the two major clusters of XDR A. baumannii disseminated in Brazil-ST15/CC15 (https://pubmlst.org/bigsdb?page=info\&db=pubmlst_abaumannii_isolates\&id=3655) and ST79/CC79 (https://pubmlst.org/bigsdb?page=info\&db=pubmlstabaumannii_isolates\&id=3647) —according to the Pasteur Institute and one (100) PDR strain that displayed resistance to all antimicrobials tested, including polymyxin. As a reference, the ATCC strain 19606 was included in all antibacterial assays.

\subsection{Peptide}

The peptide melittin used in this study was obtained from Sigma-Aldrich (St. Louis, MO, USA). The peptide was dissolved in distilled water and the solution was stored at $-20^{\circ} \mathrm{C}$.

\subsection{Determination of the Minimum Inhibitory Concentration (MIC)}

The MICs for melittin, polymyxin and imipenem were determined by the broth microdilution assays according to the recommendations of the Clinical and Laboratory Standards Institute (CLSI) [40]. After growth at $37^{\circ} \mathrm{C}$ for $24 \mathrm{~h}$ in nutrient agar medium, bacterial strains were suspended in sterile saline $(0.85 \%)$ to $0.5 \mathrm{McF}$ arland standard $\left(1 \times 10^{8} \mathrm{CFU} / \mathrm{mL}\right)$ and then diluted in the range of 1:100 in cation-adjusted Mueller Hinton (CAMH) broth ( $\mathrm{pH} 7.3$ ) to a final concentration of $1 \times 10^{6} \mathrm{CFU} / \mathrm{mL}$. Serial dilutions of the melittin and antibiotics were prepared in culture medium at a volume of $100 \mu \mathrm{L}$ in 96-well plates. The quantity of melittin ranged from 14 to $85 \mu \mathrm{g} / \mathrm{mL}$ and antibiotics from 0.125 to $64 \mu \mathrm{g} / \mathrm{mL}$. Their addition to the inoculated plates was executed in less than $30 \mathrm{~min}$ followed by mixing on the bench in rotational movement. After a $24 \mathrm{~h}$ incubation at $37^{\circ} \mathrm{C}$, bacterial growth was detected by the addition of resazurin to $0.02 \%$ and a $1 \mathrm{~h}$ incubation [41]. The lowest quantity of antibacterial agents producing complete inhibition of visible growth was considered as the MIC. Controls were included for sterility and bacterial growth along with the reference strains Escherichia coli (ATCC 25922) and P. aeruginosa (ATCC 27853) as the quality controls for the anti-microbial agents [40].

\subsection{Inhibition of Biofilm Formation}

Biofilm formation by all experimental strains was identified and quantified using a tissue culture plate (TCP) method as described previously [42], with a few modifications. Briefly, $100 \mu \mathrm{L}$ of bacterial cells suspended in LB broth (0.5 McFarland) was added to the wells of a sterile flat-bottom 96-well TCP and incubated at $37^{\circ} \mathrm{C}$ for $24 \mathrm{~h}$. After the overnight incubation, wells were washed three times with Milli-Q water and air-dried. Next, wells were stained with $100 \mu \mathrm{L}$ of $0.1 \%$ crystal violet (in water) for $30 \mathrm{~min}$. Excess stain was thoroughly removed by three washes with Milli-Q water and then allowed to dry at room temperature for $1 \mathrm{~h}$. Next, $150 \mu \mathrm{L}$ of $95 \%$ ethanol was added to each well for $15 \mathrm{~min}$. As a measurement of biofilm formation, the optical density at $590 \mathrm{~nm}$ was read on an 
ELISA plate reader (FlexStation ${ }^{\circledR} 3$ Microplate Reader; Molecular Devices). The negative control was LB broth without bacteria and A. baumannii (ATCC 19606) was used as a positive control for biofilm production. To quantify the inhibitory effect of melittin peptide on biofilm growth, the method above was employed with some modifications [43]. After overnight incubation, the culture medium was removed and $100 \mu \mathrm{L}$ of LB broth with melittin $(14 \mu \mathrm{g} / \mathrm{mL})$ was added. After a $2 \mathrm{~h}$ incubation at $37^{\circ} \mathrm{C}$, wells were washed, stained, solubilized and the OD was measured at $590 \mathrm{~nm}$. The percentage of biofilm reduction was calculated using the results from bacteria cultured in the absence of peptide. Experiments were performed three times in triplicate, and the data were averaged.

\subsection{Membrane Permeability Assay}

Cytoplasmic membrane damage was determined using steady-state fluorescence, as described before [44], with some modifications. Briefly, A. baumannii strains and the A. baumannii (ATCC 19606) reference strain were cultivated in LB medium for $24 \mathrm{~h}$. Bacterial cultures were adjusted to approximately $1 \times 10^{8}$ cells $/ \mathrm{mL}$ in LB broth before treatment with melittin $(142 \mu \mathrm{g} / \mathrm{mL})$ for $2 \mathrm{~h}$ at $37^{\circ} \mathrm{C}$. As a positive control, representative cultures of each strain were heat-treated in a water bath at $65^{\circ} \mathrm{C}$ for $15 \mathrm{~min}$ while untreated bacteria were used as a negative control. Next, cultures were incubated with $30 \mu \mathrm{M}$ of propidium iodide (PI) at $37^{\circ} \mathrm{C}$ for $15 \mathrm{~min}$ in the dark. Cells were collected and washed three times in PBS by centrifugation (4000 $\times g$ for $15 \mathrm{~min}$ ). A final cell suspension was smeared onto a glass slide for imaging on an Axio Imager M2 microscope (Carl Zeiss). Both fluorescence and differential interference contrast (DIC) images were captured for each field of view from multiple areas for the analysis of each treatment group. The DIC image was used for bacteria segmentation and the percentage of PI-positive bacteria was evaluated using Knime workflow. The results from two independent cultures are reported.

\subsection{Analysis of Bacterial Proliferation}

A. baumannii strains were cultivated in LB medium for $24 \mathrm{~h}$ and cell concentration was adjusted as described above. Then, cells were incubated with $20 \mu \mathrm{M}$ of carboxyfluorescein succinimidyl ester (CFSE) for $20 \mathrm{~min}$ and centrifuged for $5 \mathrm{~min}(4000 \times g)$ to remove culture supernatant. After incubation with CFSE, cells were treated with melittin $(142 \mu \mathrm{g} / \mathrm{mL})$ for $2 \mathrm{~h}$ at $37^{\circ} \mathrm{C}$. Bacteria were collected and washed three times in PBS by centrifugation $(4000 \times g$ for $15 \mathrm{~min})$. The bacterial suspension was analyzed in an Axio Imager M2 microscope (Carl Zeiss).

\subsection{Statistical Analysis}

Statistical analysis and graphics were performed using R (version 3.6.0) and RStudio. The statistical difference was considered if $p<0.05$ using a $t$-test and one-way ANOVA.

\section{Results}

\subsection{Determination of MIC for Melittin, Polymyxin and Imipenem in A. baumannii Strains}

A. baumannii 100 showed resistance for both polymyxin and Imipenem with a MIC value of 8 and $32 \mu \mathrm{g} / \mathrm{mL}$, respectively. A. baumannii 33677 and 96734 were considered XDR with high MIC only for imipenem $(16 \mu \mathrm{g} / \mathrm{mL})$. The distribution of MIC for polymyxin and imipenem for $A$. baumannii strains are summarized in Table 1.

\subsection{Biofilm Formation Test}

The MIC values of melittin determined for all A. baumannii strains showed good activity, with MIC values ranging between 17 and $45.5 \mu \mathrm{g} / \mathrm{mL}$, except for the PDR strain 100, that maintained viability even in higher concentrations of melittin $(284 \mu \mathrm{g} / \mathrm{mL})$ (Table 1). After the addition of resazurin, a well-known indicator dye for the assessment of viability in both microbial and cell culture applications [45], the fluorescence analysis revealed that $90 \%$ of cells were killed at MIC values for all strains, except PDR strain. 
Table 1. Measured minimum inhibitory concentration (MIC) values for melittin, polymyxin and imipenem.

\begin{tabular}{|c|c|c|c|}
\hline Strain/Resistance Profile & Melittin $(\mu \mathrm{g} / \mathrm{mL})$ & Polymyxin ${ }^{c}(\mu \mathrm{g} / \mathrm{mL})$ & Imipenem $^{d}(\mu \mathrm{g} / \mathrm{mL})$ \\
\hline A. baumannii ATCC 19606 & 17 & 0.25 & 0.25 \\
\hline A. baumannii $31852(\mathrm{~S})$ & 20 & 0.25 & $\leq 0.125$ \\
\hline A. baumannii 33677 (XDR) & 31 & 0.25 & 16 \\
\hline A. baumannii 96734 (XDR) & 45.5 & 0.25 & 16 \\
\hline A. baumannii $100\left(\mathrm{PDR}^{\mathrm{b}}\right)$ & $>284$ & 8 & 32 \\
\hline
\end{tabular}

After the biofilm formation and staining processes, absorbance analysis at $580 \mathrm{~nm}$ revealed that A. baumannii ATCC 19606 (the reference strain), 33677 and 96734 formed a weak biofilm, whereas susceptible (31852) and PDR (100) strains formed a moderate biofilm. Despite the observation that susceptible strain 31852 produced a more significant biofilm, reaching approximately 2-fold increase compared to 33677, 96734 and ATCC strains, the melittin activity at sub-inhibitory concentrations $(14 \mu \mathrm{g} / \mathrm{mL})$ affected this strain to a high degree. Melittin treatment significantly reduced its formation of bacterial sessile aggregate by approximately $30 \%$. Melittin did not affect other strains at low tested concentrations (Figure 1).

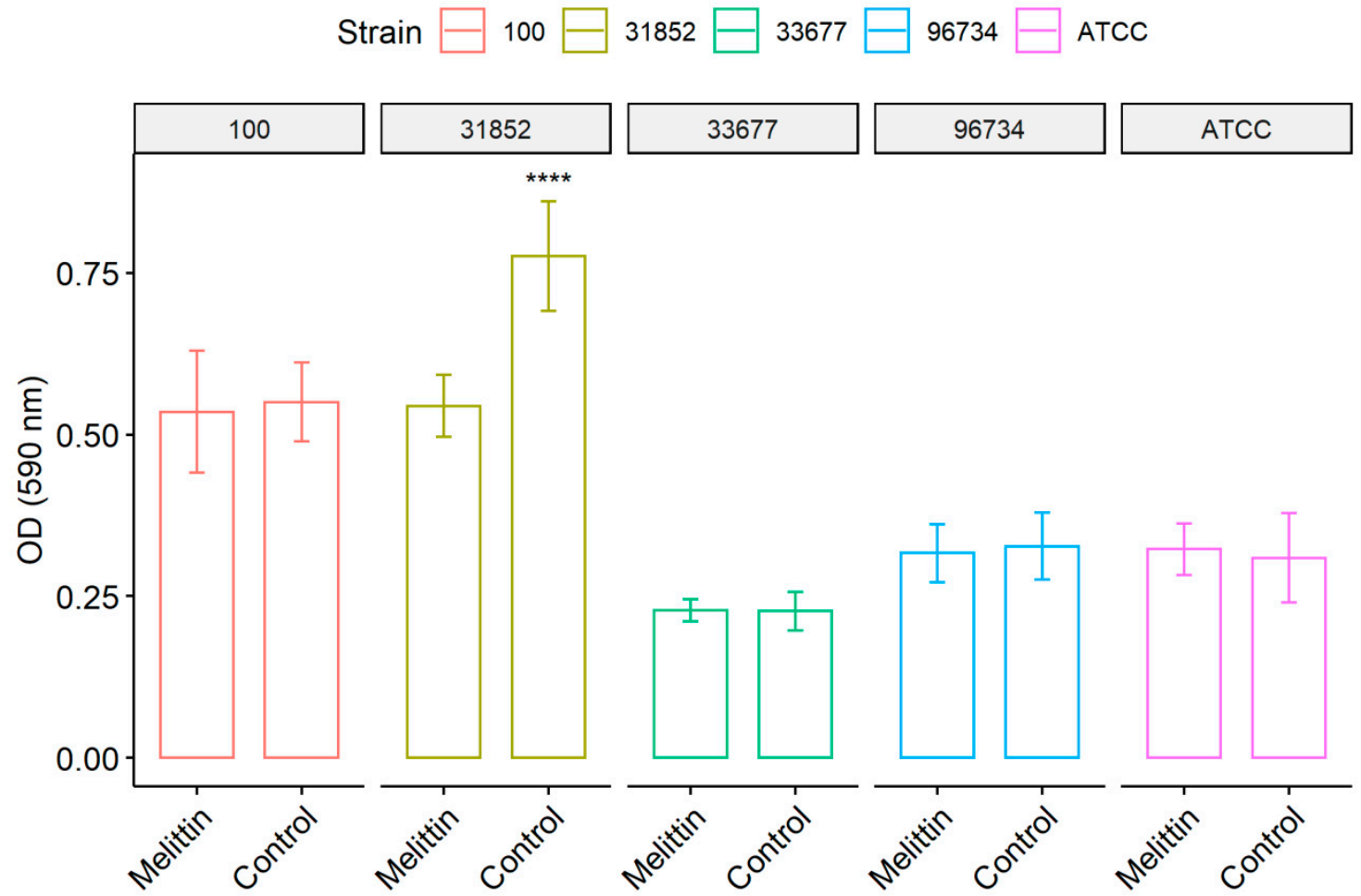

Figure 1. The action of melittin on biofilms of A. baumannii strains. Bacteria were allowed to grow in 96-well plates; after $24 \mathrm{~h}$, the biofilms were treated with melittin $(142 \mu \mathrm{g} / \mathrm{mL})$ and after $2 \mathrm{~h}$ the biofilms were quantified by staining with crystal violet. Control represents untreated groups. Results represent the mean and standard deviation of at least three independent experiments. ${ }^{* * * *}$ Statistically significant $(p<0.001)$ using $t$-test.

Analysis of PI staining, a membrane permeability indicator, revealed that bacterial membranes of strains from ATCC were strongly affected by melittin along with pan-resistant strain 100 (Figure 2). Melittin effects on bacterial membrane were evidenced significantly in ATCC, 100 and 31852 strains, 
as the treatment with this peptide increased in media 13-, 6- and 48-fold membrane disruption, respectively, compared to untreated control. In the reference strain ATCC, melittin produced more damage to the bacteria than the heat-treated positive control. As expected, positive control values maintained a high number of PI fluorescent cells, ranging from 39\% to 53\%.

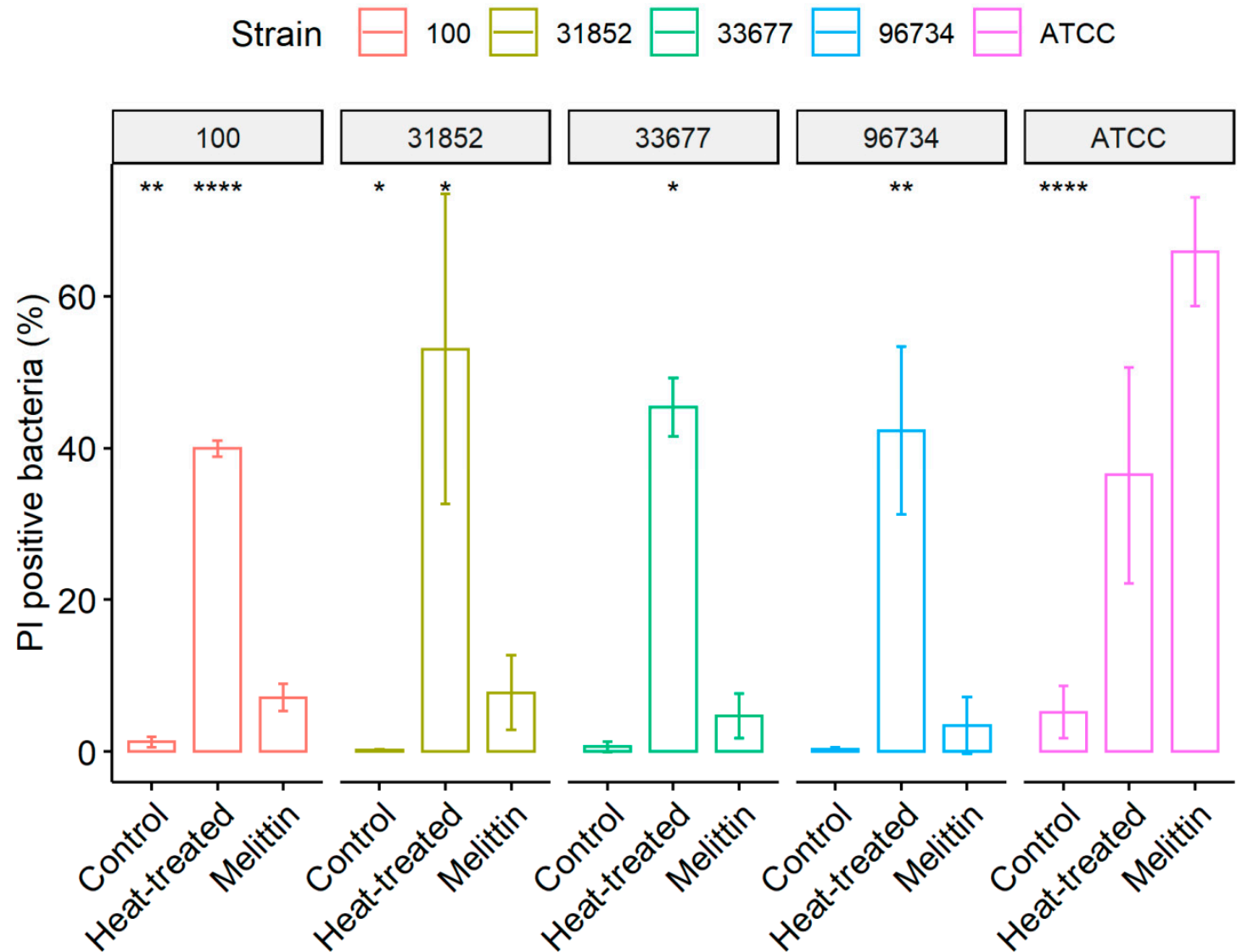

Figure 2. Effect of melittin in bacterial membrane permeability. Different A. baumannii strains were treated with melittin $(142 \mu \mathrm{g} / \mathrm{mL})$ for $2 \mathrm{~h}$ or heat-treated at $65^{\circ} \mathrm{C}$ for $15 \mathrm{~min}$, then incubated with the nucleic acid probe propidium iodide (PI; $30 \mu \mathrm{M}$ ), as a membrane permeability indicator. Bars indicate the percentage of PI fluorescent bacteria in the untreated group, treated with melittin or heat-treated. Results represent the mean and standard deviation. Statistically different $\left({ }^{*} p<0.05,{ }^{* *} p<0.01\right.$ and $* * * * p<0.001)$ from melittin group using $t$-test.

To evaluate if melittin exerts a bacteriostatic effect on the A. baumannii strains, bacterial cells were stained with CFSE, a cell-permeable fluorescent dye used to monitor cell division (Figure 3). Fluorescence was low in untreated cells of the reference strain from ATCC and merged images showed a high number of unlabeled bacteria, indicating cell division (Figure 3A). In contrast, melittin treatment inhibited the proliferation of this strain, which retained a higher fluorescent signal in the bacterial cytoplasm from an absence of dye dilution during cell division (Figure 3B). Nearly all bacteria observed by DIC showed fluorescence. Untreated bacteria of the PDR strain showed few fluorescent cells as expected (Figure 3C). Melittin treatment did not appear to cause any discernable bacteriostatic effect with few cells still emitting fluorescence as the majority of bacteria were not stained, which correlates to a high proliferation rate (Figure 3D). 


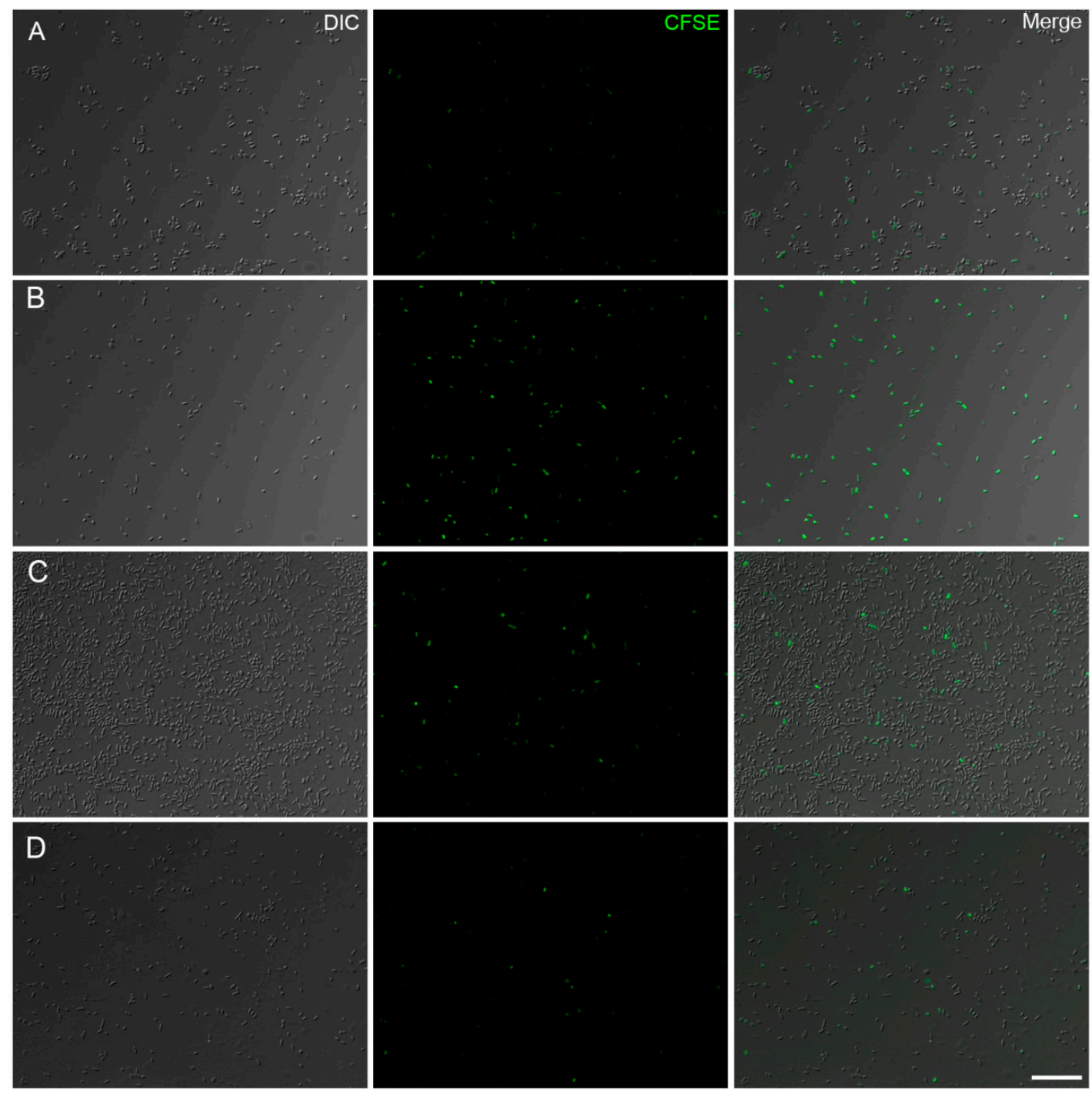

Figure 3. Fluorescence images of CFSE stained A. baumannii after treatment with melittin $(142 \mu \mathrm{g} / \mathrm{mL})$ for $2 \mathrm{~h}$ at $37^{\circ} \mathrm{C}$. The proliferation of untreated bacteria (A) and bacteriostatic effect of melittin against ATCC strain (B). A. baumannii PDR strain 100 images of CFSE-labeled bacteria from untreated (C) and melittin treated cells (D). DIC: Differential interference contrast. Bar $=20 \mu \mathrm{m}$.

\section{Discussion}

Extensive exposure to antibiotics has rapidly increased the propagation of MDR, XDR and PDR bacteria, often dubbed superbugs, which complicates the choice of chemotherapeutics and limits treatment options [46,47]. The increase in antibiotic resistance during biofilm infections is a substantial problem in public health and underlies the need for new, effective solutions. In terms of nosocomial infections, morbidity and mortality due to MDR biofilm-producing A. baumannii are of great concern $[18,48]$. This problem is directly associated with the ability of bacteria to survive and endure in the patient's body or hospital environment due to biofilm layer production, which is driven by several of yet to be defined molecular mechanisms that lower the diffusion of antibiotics and increase antimicrobial recalcitrance [1,39].

Several strategies have been proposed over the years in an attempt to efficiently treat bacterial biofilms, including prevention, weakening, disruption or killing [49]. Among the limited numbers of new antimicrobials in the pipeline, natural peptides from animal venoms have been demonstrated to possess promising biological properties, which warrant their development as efficacious agents against recalcitrant pathogens [50-52]. Among them, melittin from bee venom has been proven to 
have potent antibacterial activity [31]. There are multiple lines of evidence and several studies that confirm the antibacterial activity of melittin toward antibiotic-resistant bacteria [31,53-57].

Therefore, our study focused on the evaluation of melittin for its in vitro microbicide activity, antibiofilm activity and membrane damage against $A$. baumannii strains isolated from primary infections from hospitals in Brazil with different antibiotic sensitivity profiles. The MICs of melittin, polymyxin, and imipenem against $A$. baumannii strains were compared. According to the results, one isolate was susceptible to imipenem and polymyxin, two were resistant to imipenem and susceptible to polymyxin and one was resistant to both. As a control, susceptibility of A. baumannii ATCC 19606 was monitored in this study and the results agreed with previous studies $[10,58]$. The MICs for melittin ranged from 17 to $45.5 \mu \mathrm{g} / \mathrm{mL}$, except for PDR that was resistant up to $284 \mu \mathrm{g} / \mathrm{mL}$. A recent survey reported the synergistic antibacterial, biofilm inhibition and biofilm removal activities of melittin in combination with several antibiotics against MDR, a strong biofilm producer A. baumannii strains from clinical isolates. Significant synergistic behaviors were observed combining melittin with colistin and imipenem [57], corroborating previous findings reported by Giacometti et al. in 2003 [59].

The sub-inhibitory concentration of melittin only inhibited biofilm formation of the A. baumannii susceptible strain (31852). However, melittin is very effective against biofilm-producing P. aeruginosa clinical isolates, with a minimum biofilm inhibition concentration (MBIC) range of 4-16 $\mu \mathrm{M}$, which was far more active compared to certain antibiotics including ampicillin, chloramphenicol and levofloxacin [56]. Moreover, melittin has been reported to inhibit either biofilm formation or bacterial surface attachment in a time-dependent manner [31]. The peptide was also capable of inhibiting five-strong biofilm-producer strains of MDR A. baumannii and inhibiting their biofilm formations, alone or in combination with colistin and imipenem [57]. Noticeably, melittin lessened both biofilm biomass and the viability of biofilm-embedded Borrelia burgdorferi strain B31 at different concentrations in comparison to PBS-treated biofilms, which was further confirmed by SYBR Green I/(PI) assay and atomic force microscopy [60]. Another study reported that melittin inhibited biofilm production and destroyed bacterial biofilms [53]. A recent survey implied that melittin was able to penetrate biofilm layers of $P$. aeruginosa gradually and to kill biofilm-residing bacteria kinetically by disrupting the bacterial membrane [61]. Collectively, these shreds of evidence suggest that melittin can decrease biofilm formation, biofilm biomass, and the viability of bacteria within biofilms in a time- and concentration-dependent manner.

The mechanisms of action of antimicrobial peptides against bacteria are diverse. AMPs can act in membrane permeabilization, intracellular targets, and modulation of the immune response [62]. Several lines of evidence suggest that the main mechanism of action of melittin is the formation of toroidal pores in the bacterial membrane $[63,64]$. Resistant strains were less susceptible to melittin, possibly due to surface modifications in the outer membrane, such as charge modification in lipopolysaccharides driven by phosphorylation, sugar and lipid substitutions [65].

Lipopolysaccharides play a major role in bacterial resistance. Polymyxin B resistance is driven by modifications of lipid A, which decrease electrostatic attraction between the peptide and bacterial membrane [66]. Other mechanisms of resistance against AMPs include proteolytic cleavage, efflux of AMPs that act on intracellular targets and entrapment by matrix proteins and polysaccharides that block AMPs or cause electrostatic repulsion of cationic peptides [65]. Melittin produced a small damage in the bacterial membrane even in a PDR strain subpopulation, but it was not sufficient to efficiently kill this strain. Increased membrane permeability is promising for a drug combination approach against PDR or to avoid resistance. The co-administration of antibiotics with permeability enhancing compounds can enhance activity due to an increase of drug with permeability [67]. Several investigations have addressed possible synergistic effects between melittin and other anti-microbial agents, in particular, conventional antibiotics $[55,57,59,68,69]$. 


\section{Conclusions}

The rapid rise of bacterial resistance to currently available antibiotics is one of the major threats to the human population, especially in hospital settings. The development of new effective antibiotics is urgently needed, and peptides are a promising source of microbicidal agents. AMPs such as melittin from bee venom are an interesting alternative for killing resistant strains and to stop their biofilm formation as a remedy for de-contaminating fomites. Evaluation of melittin against Brazilian clinical strains revealed that most strains were susceptible, except for the PDR 100 strain. An analysis of the mechanisms of action suggested that melittin altered the permeability of the plasma membrane, even in a subpopulation of PDR. However, the extent of damage detected in the PDR strain was not sufficient to retard bacterial growth. Collectively, the results further demonstrate that the emergence of "superbugs" and the importance of a continued search for alternative molecules to provide effective remedies. Melittin displayed promising activity against XDR, which suggests that modifications to the peptide sequence could enhance its activity against antibiotic-resistant bacteria to address their threat to public health. Without immediate and global action, the world population is headed for a dangerous post-antibiotic era [33]. Melittin is a highly potent antibacterial agent that may have a good synergistic effect on killing the bacteria and also inhibiting biofilm formation [53].

Author Contributions: Supervision of the studies/project: S.G.D.S.; conceived and designed the experiments: K.R.; performed the experiments: K.R., A.L.A.S., J.P.R.d.S.C. and M.H.S.V.B.; analyzed the data: G.C.L., S.G.D.S.; contributed reagents/materials/analysis tools: S.G.D.S.; Wrote the paper: K.R., S.G.D.S. All authors have read and agreed to the published version of the manuscript.

Funding: Salvatore Giovanni De Simone receives support from the Brazilian Council for Scientific Research (CNPq \# 467.488.2014-2; \#3075732011; \#3013322015-0), Carlos Chagas Filho Foundation for Research Support of the State of Rio de Janeiro (FAPERJ \# 110.198-13; \# 202.841-2018) and Higher Education Coordination of Improvement (CAPES \# 001-2010).

Acknowledgments: We thank D. William Provance, Jr for reviewing the English. Karyne Rangel and Guilherme Curty Lechuga are Post-doc fellows from CAPES/CDTS and INCT-IDN, respectively.

Conflicts of Interest: The authors declare no conflict of interest.

\section{References}

1. Qi, L.; Li, H.; Zhang, C.; Liang, B.; Li, J.; Wang, L.; Du, X.; Liu, X.; Qiu, S.; Song, H. Relationship between antibiotic resistance, biofilm formation, and biofilm-specific resistance in Acinetobacter baumannii. Front. Microbiol. 2016, 7, 483. [CrossRef]

2. Safari, M.; Mozaffari Nejad, A.S.; Bahador, A.; Jafari, R.; Alikhani, M.Y. Prevalence of ESBL and MBL encoding genes in Acinetobacter baumannii strains isolated from patients of intensive care units (ICU). Saudi J. Biol. Sci. 2015, 22, 424-429. [CrossRef]

3. Wong, D.; Nielsen, T.B.; Bonomo, R.A.; Pantapalangkoor, P.; Luna, B.; Spellberg, B. Clinical and pathophysiological overview of Acinetobacter infections: A century of challenges. Clin. Microbiol. Rev. 2017, 30, 409-447. [CrossRef]

4. Harding, C.M.; Hennon, S.W.; Feldman, M.F. Uncovering the mechanisms of Acinetobacter baumannii virulence. Nat. Rev. Microbiol. 2018, 16, 91-102. [CrossRef]

5. Center for Disease Control and Prevention (CDC). Antibiotic Resistance Threats in the United States, USA; CDC: Atlanta, GA, USA, 2013.

6. Paterson, D.L.; Bonomo, R.A. Multidrug-resistant gram-negative pathogens: The urgent need for 'old' polymyxins. Adv. Exp. Med. Biol. 2019, 1145, 9-13. [PubMed]

7. Romanin, P.; Palermo, R.L.; Cavalini, J.F.; Fávaro, L.D.S.; De Paula-Petroli, S.B.; Fernandes, E.V.; Dos Anjos Szczerepa, M.M.; Tognim, M.C.B.; Yamada-Ogatta, S.F.; Carrara-Marroni, F.E.; et al. Multidrug- and extensively drug-resistant Acinetobacter baumannii in a tertiary hospital from Brazil: The importance of carbapenemase encoding genes and epidemic clonal complexes in a 10-year study. Microb. Drug Resist. 2019, 25, 1365-1373. [CrossRef] [PubMed]

8. Mao, T.; Zhai, H.; Duan, G.; Yang, H. Patterns of drug-resistant bacteria in a general hospital, China, 2011-2016. Pol. J. Microbiol. 2019, 68, 225-232. [CrossRef] [PubMed] 
9. World Health Organization (WHO). WHO Publishes List of Bacteria for Which New Antibiotics Are Urgently Needed; WHO: Geneva, Switzerland, 2017.

10. Bardbari, A.M.; Arabestani, M.R.; Karami, M.; Keramat, F.; Alikhani, M.Y.; Bagheri, K.P. Correlation between ability of biofilm formation with their responsible genes and MDR patterns in clinical and environmental Acinetobacter baumannii isolates. Microb. Pathog. 2017, 108, 122-128. [CrossRef]

11. Howard, A.; O'Donoghue, M.; Feeney, A.; Sleator, R.D. Acinetobacter baumannii: An emerging opportunistic pathogen. Virulence 2012, 3, 243-250. [CrossRef]

12. Dahdouh, E.; Orgaz, B.; Gómez-Gil, R.; Mingorance, J.; Daoud, Z.; Suarez, M.; San Jose, C. Patterns of biofilm structure and formation kinetics among Acinetobacter baumannii clinical isolates with different antibiotic resistance profiles. Med. Chem. Commun. 2016, 7, 157-163. [CrossRef]

13. Batoni, G.; Maisetta, G.; Esin, S. Antimicrobial peptides and their interaction with biofilms of medically relevant bacteria. Biochim. Biophys. Acta 2016, 1858, 1044-1060. [CrossRef] [PubMed]

14. Gunn, J.S.; Bakaletz, L.O.; Wozniak, D.J. What's on the outside matters: The role of the extracellular polymeric substance of Gram-negative biofilms in evading host immunity and as a target for therapeutic intervention. J. Biol. Chem. 2016, 291, 12538-12546. [CrossRef] [PubMed]

15. Ramos-Gallardo, G. Chronic wounds in burn injury: A case report on importance of biofilms. World J. Plast. Surg. 2016, 5, 175-180. [PubMed]

16. Vila-Farres, X.; Garcia de la Maria, C.; López-Rojas, R.; Pachón, J.; Giralt, E.; Vila, J. In Vitro activity of several antimicrobial peptides against colistin-susceptible and colistin-resistant Acinetobacter baumannii. Clin. Microbiol. Infect. 2012, 18, 383-387. [CrossRef]

17. Sun, F.; Qu, F.; Ling, Y.; Mao, P.; Xia, P.; Chen, H.; Zhou, D. Biofilm-associated infections: Antibiotic resistance and novel therapeutic strategies. Future Microbiol. 2013, 8, 877-886. [CrossRef]

18. Lashinsky, J.N.; Henig, O.; Pogue, J.M.; Kaye, K.S. Minocycline for the treatment of multidrug and extensively drug-resistant A. baumannii: A review. Infect. Dis. Ther. 2017, 6, 199-211. [CrossRef]

19. Greene, C.; Wu, J.; Rickard, A.H.; Xi, C. Evaluation of the ability of Acinetobacter baumannii to form biofilms on six different biomedical relevant surfaces. Lett. Appl. Microbiol. 2016, 63, 233-239. [CrossRef]

20. Sierra, J.M.; Fusté, E.; Rabanal, F.; Vinuesa, T.; Viñas, M. An overview of antimicrobial peptides and the latest advances in their development. Expert Opin. Biol. Ther. 2017, 17, 663-676. [CrossRef]

21. Nuti, R.; Goud, N.S.; Saraswati, A.P.; Alvala, R.; Alvala, M. Antimicrobial peptides: A promising therapeutic strategy in tackling antimicrobial resistance. Curr. Med. Chem 2017, 24, 4303-4314. [CrossRef]

22. Wimley, W.C. Describing the mechanism of antimicrobial peptide action with the interfacial activity model. ACS Chem. Biol. 2010, 5, 905-917. [CrossRef]

23. Zasloff, M. Antimicrobial peptides of multicellular organisms. Nature 2002, 415, 389-395. [CrossRef]

24. Koehbach, J.; Craik, D.J. The vast structural diversity of antimicrobial peptides. Trends Pharmacol. Sci. 2019, 40,517-528. [CrossRef]

25. Fox, J.L. Antimicrobial peptides stage a comeback. Nat. Biotechnol. 2013, 31, 379-382. [CrossRef]

26. Dosler, S.; Karaaslan, E. Inhibition and destruction of Pseudomonas aeruginosa biofilms by antibiotics and antimicrobial peptides. Peptides 2014, 62, 32-37. [CrossRef]

27. Rios, A.C.; Moutinho, C.G.; Pinto, F.C.; Del Fiol, F.S.; Jozala, A.; Chaud, M.V.; Vila, M.M.; Teixeira, J.A.; Balcão, V.M. Alternatives to overcoming bacterial resistances: State-of-the-art. Microbiol. Res. 2016, 191, 51-80. [CrossRef]

28. Memariani, H.; Memariani, M.; Shahidi-Dadras, M.; Nasiri, S.; Akhavan, M.M.; Moravvej, H. Melittin: From honeybees to superbugs. Appl. Microbiol. Biotechnol. 2019, 103, 3265-3276. [CrossRef]

29. Dorman, L.C.; Markley, L.D. Solid phase synthesis and antibacterial activity of N-terminal sequences of melittin. J. Med. Chem. 1971, 14, 5-9. [CrossRef]

30. Steiner, H.; Hultmark, D.; Engström, Å.; Bennich, H.; Boman, H.G. Sequence and specificity of two antibacterial proteins involved in insect immunity. Nature 1981, 292, 246-248. [CrossRef]

31. Dosler, S.; Karaaslan, E.; Alev Gerceker, A. Antibacterial and anti-biofilm activities of melittin and colistin, alone and in combination with antibiotics against Gram-negative bacteria. J. Chemother. 2016, 28, 95-103. [CrossRef]

32. Pashaei, F.; Bevalian, P.; Akbari, R.; Pooshang Bagheri, K. Single dose eradication of extensively drug resistant Acinetobacter spp. In a mouse model of burn infection by melittin antimicrobial peptide. Microb. Pathog. 2019, 127, 60-69. [CrossRef] 
33. Sugden, R.; Kelly, R.; Davies, S. Combatting antimicrobial resistance globally. Nat. Microbiol. 2016, 1, 16187. [CrossRef]

34. Yang, L.; Harroun, T.A.; Weiss, T.M.; Ding, L.; Huang, H.W. Barrel-stave model or toroidal model? A case study on melittin pores. Biophys. J. 2001, 81, 1475-1485. [CrossRef]

35. Rady, I.; Siddiqui, I.A.; Rady, M.; Mukhtar, H. Melittin, a major peptide component of bee venom, and its conjugates in cancer therapy. Cancer Lett. 2017, 402, 16-31. [CrossRef]

36. Andersson, M.; Ulmschneider, J.P.; Ulmschneider, M.B.; White, S.H. Conformational states of melittin at a bilayer interface. Biophys. J. 2013, 104, L12-L14. [CrossRef]

37. Lee, M.-T.; Sun, T.-L.; Hung, W.-C.; Huang, H.W. Process of inducing pores in membranes by melittin. Proc. Natl. Acad. Sci. USA 2013, 110, 14243-14248. [CrossRef]

38. Wu, Y.; Ma, L.; Cheley, S.; Bayley, H.; Cui, Q.; Chapman, E.R. Permeation of styryl dyes through nanometer-scale pores in membranes. Biochemistry 2011, 50, 7493-7502. [CrossRef]

39. Paull, B.R.; Yunginger, J.W.; Gleich, G.J. Melittin: An allergen of honeybee venom. J. Allergy Clin. Immunol. 1977, 59, 334-338. [CrossRef]

40. Clinical and Laboratory Standands Institute (CLSI). Performance Standards for Antimicrobial Susceptibility Testing; CLSI approved standard M100-S25; CLSI: Wayne, PA, USA, 2015.

41. Lall, N.; Henley-Smith, C.J.; De Canha, M.N.; Oosthuizen, C.B.; Berrington, D. Viability reagent, prestoblue, in comparison with other available reagents, utilized in cytotoxicity and antimicrobial assays. Int. J. Microbiol. 2013, 2013, 420601. [CrossRef]

42. Moskowitz, S.M.; Foster, J.M.; Emerson, J.; Burns, J.L. Clinically feasible biofilm susceptibility assay for isolates of Pseudomonas aeruginosa from patients with cystic fibrosis. J. Clin. Microbiol. 2004, 42, 1915-1922. [CrossRef]

43. Eales, M.G.; Ferrari, E.; Goddard, A.D.; Lancaster, L.; Sanderson, P.; Miller, C. Mechanistic and phenotypic studies of bicarinalin, BP100 and colistin action on Acinetobacter baumannii. Res. Microbiol. 2018, 169, $296-302$. [CrossRef]

44. Tyagi, P.; Singh, M.; Kumari, H.; Kumari, A.; Mukhopadhyay, K. Bactericidal activity of curcumin I is associated with damaging of bacterial membrane. PLoS ONE 2015, 10, e0121313. [CrossRef] [PubMed]

45. Travnickova, E.; Mikula, P.; Oprsal, J.; Bohacova, M.; Kubac, L.; Kimmer, D.; Soukupova, J.; Bittner, M. Resazurin assay for assessment of antimicrobial properties of electrospun nanofiber filtration membranes. AMB Express 2019, 9, 183. [CrossRef] [PubMed]

46. Deslouches, B.; Steckbeck, J.D.; Craigo, J.K.; Doi, Y.; Burns, J.L.; Montelaro, R.C. Engineered cationic antimicrobial peptides to overcome multidrug resistance by ESKAPE pathogens. Antimicrob. Agents Chemother. 2015, 59, 1329-1333. [CrossRef] [PubMed]

47. Mohamed, M.F.; Brezden, A.; Mohammad, H.; Chmielewski, J.; Seleem, M.N. Targeting biofilms and persisters of ESKAPE pathogens with P14KanS, a kanamycin peptide conjugate. Biochim. Biophys. Acta Gen. Subj. 2017, 1861, 848-859. [CrossRef]

48. Wang, C.; Wang, J.; Pan, H.; Hu, W.; Li, Y. Multidrug resistance and biofilm formation contribute to the nosocomial infections caused by Acinetobacter baumannii. In The Battle against Microbial Pathogens: Basic Science, Technological Advances and Educational Programs; Méndez-Vilas, A., Ed.; Formatex Research Center: Badajoz, Spain, 2015; Volume 1, pp. 452-461.

49. Bjarnsholt, T.; Ciofu, O.; Molin, S.; Givskov, M.; Høiby, N. Applying insights from biofilm biology to drug development-Can a new approach be developed? Nat. Rev. Drug. Discov. 2013, 12, 791-808. [CrossRef]

50. Hale, J.D.; Hancock, R.E. Alternative mechanisms of action of cationic antimicrobial peptides on bacteria. Expert Rev. Anti-Infect. Ther. 2007, 5, 951-959. [CrossRef]

51. Memariani, H.; Shahbazzadeh, D.; Ranjbar, R.; Behdani, M.; Memariani, M.; Pooshang Bagheri, K. Design and characterization of short hybrid antimicrobial peptides from pEM-2, mastoparan-VT1, and mastoparan-B. Chem. Biol. Drug. Des. 2017, 89, 327-338. [CrossRef]

52. Almeida, J.R.; Palacios, A.L.V.; Patiño, R.S.P.; Mendes, B.; Teixeira, C.A.S.; Gomes, P.; da Silva, S.L. Harnessing snake venom phospholipases A2 to novel approaches for overcoming antibiotic resistance. Drug Dev. Res. 2019, 80, 68-85. [CrossRef] 
53. Picoli, T.; Peter, C.M.; Zani, J.L.; Waller, S.B.; Lopes, M.G.; Boesche, K.N.; Vargas, G.D.Á.S.; Hübner, O.; Fischer, G. Melittin and its potential in the destruction and inhibition of the biofilm formation by Staphylococcus aureus, Escherichia coli and Pseudomonas aeruginosa isolated from bovine milk. Microb. Pathog. 2017, 112, 57-62. [CrossRef]

54. Shi, W.; Li, C.; Li, M.; Zong, X.; Han, D.; Chen, Y.C. Antimicrobial peptide melittin against Xanthomonas oryzae pv. oryzae, the bacterial leaf blight pathogen in rice. Appl. Microbiol. Biotechnol. 2016, 100, 5059-5067. [CrossRef]

55. Dosler, S.; Gerceker, A.A. In Vitro activities of antimicrobial cationic peptides; melittin and nisin, alone or in combination with antibiotics against Gram-positive bacteria. J. Chemother. 2012, 24, 137-143. [CrossRef]

56. Gopal, R.; Lee, J.H.; Kim, Y.G.; Kim, M.S.; Seo, C.H.; Park, Y. Antimicrobial, anti-biofilm activities and cell selectivity of the NRC-16 peptide derived from witch flounder, Glyptocephalus cynoglossus. Mar. Drugs 2013, 11, 1836-1852. [CrossRef]

57. Bardbari, A.M.; Arabestani, M.R.; Karami, M.; Keramat, F.; Aghazadeh,H.; Alikhani, M.Y.; Bagheri, K.P. Highly synergistic activity of melittin with imipenem and colistin in biofilm inhibition against multidrug-resistant strong biofilm producer strains of Acinetobacter baumannii. Eur. J. Clin. Microbiol. Infect. Dis. 2018, 37, 443-454. [CrossRef]

58. Ying, C.; Li, Y.; Wang, Y.; Zheng, B.; Yang, C. Investigation of the molecular epidemiology of Acinetobacter baumannii isolated from patients and environmental contamination. J. Antibiot. (Tokyo) 2015, 68, 562-567. [CrossRef]

59. Giacometti, A.; Cirioni, O.; Kamysz, W.; D’Amato, G.; Silvestri, C.; Del Prete, M.S.; Lukasiak, J.; Scalise, G. Comparative activities of cecropin A, melittin, and cecropin A-melittin peptide CA(1-7) $\mathrm{M}(2-9) \mathrm{NH}_{2}$ against multidrug-resistant nosocomial isolates of Acinetobacter baumannii. Peptides 2003, 24, 1315-1318. [CrossRef]

60. Socarras, K.M.; Theophilus, P.A.S.; Torres, J.P.; Gupta, K.; Sapi, E. Antimicrobial activity of bee venom and melittin against Borrelia burgdorferi. Antibiotics 2017, 6, 31. [CrossRef]

61. Khozani, R.S.; Shahbazzadeh, D.; Harzandi, N.; Feizabadi, M.M.; Bagheri, K.P. Kinetics study of antimicrobial peptide, melittin, in simultaneous biofilm degradation and eradication of potent biofilm producing MDR Pseudomonas aeruginosa isolates. Int. J. Pept. Res. Ther. 2018, 25, 329-338. [CrossRef]

62. Kumar, P.; Kizhakkedathu, J.N.; Straus, S.K. Antimicrobial peptides: Diversity, mechanism of action and strategies to improve the activity and biocompatibility in vivo. Biomolecules 2018, 8, 4. [CrossRef]

63. Park, S.C.; Kim, J.Y.; Shin, S.O.; Jeong, C.Y.; Kim, M.H.; Shin, S.Y.; Cheong, G.W.; Park, Y.; Hahm, K.S. Investigation of toroidal pore and oligomerization by melittin using transmission electron microscopy. Biochem. Biophys. Res. Commun. 2006, 343, 222-228. [CrossRef]

64. Sengupta, D.; Leontiadou, H.; Mark, A.E.; Marrink, S.J. Toroidal pores formed by antimicrobial peptides show significant disorder. Biochim. Biophys. Acta 2008, 1778, 2308-2317. [CrossRef]

65. Bechinger, B.; Gorr, S.-U. Antimicrobial peptides: Mechanisms of action and resistance. J. Dent. Res. 2017, 96, 254-260. [CrossRef] [PubMed]

66. Nikaido, H. Molecular basis of bacterial outer membrane permeability revisited. Microbiol. Mol. Biol. Rev. 2003, 67, 593-656. [CrossRef] [PubMed]

67. Hurdle, J.G.; O’Neill, A.J.; Chopra, I.; Lee, R.E. Targeting bacterial membrane function: An underexploited mechanism for treating persistent infections. Nat. Rev. Microbiol. 2011, 9, 62-75. [CrossRef] [PubMed]

68. Moerman, L.; Bosteels, S.; Noppe, W.; Willems, J.; Clynen, E.; Schoofs, L.; Thevissen, K.; Tytgat, J.; Van Eldere, J.; Van Der Walt, J.; et al. Antibacterial and antifungal properties of alpha-helical, cationic peptides in the venom of scorpions from southern Africa. Eur. J. Biochem. 2002, 269, 4799-4810. [CrossRef]

69. Al-Ani, I.; Zimmermann, S.; Reichling, J.; Wink, M. Pharmacological synergism of bee venom and melittin with antibiotics and plant secondary metabolites against multi-drug resistant microbial pathogens. Phytomedicine 2015, 22, 245-255. [CrossRef]

(C) 2020 by the authors. Licensee MDPI, Basel, Switzerland. This article is an open access article distributed under the terms and conditions of the Creative Commons Attribution (CC BY) license (http://creativecommons.org/licenses/by/4.0/). 